\title{
Regression Analysis of Factors Influencing Volume of Households' Savings in the V4 Countries
}

\author{
Alena Andrejovská \\ Faculty of Economics, Department of Finance, Technical University of Košice, Slovakia \\ alena.andrejovska@tuke.sk \\ Ján Buleca \\ Faculty of Economics, Department of Finance, Technical University of Košice, Slovakia \\ jan.buleca@tuke.sk
}

\section{Doi:10.5901/mjss.2016.v7n1p213}

\section{Abstract}

In the Visegrad Four countries (V4) as well as all across the Euro area the household savings rate declined to a level of $12,8 \%$ in 2014, despite the fact that the real household income per capita in the Euro area increased by 0,2\%. Aim of the submitted article concerns the empirical analysis of the relationship between savings and selected macroeconomic factors. The analysis provides a complete view to assess developments in household savings in the Visegrad Four countries within the period 20052014 and subsequently assess the impact of selected macroeconomic factors using multivariate regression analysis. Analysis solves linear relationship between savings as a dependent variable, and independent variables such as disposable income, gross domestic product, unemployment rate and inflation rate. Results of the analysis confirmed that a statistically significant model parameters and the most important determinant with strongly positive impact in all the surveyed countries was the disposable income.

Keywords: savings, gross domestic product, disposable income, macroeconomic factors

\section{Introduction}

Households as important part of every economy, their budgets and savings are permanently in focus of scientific research. Main trends in European household behaviour are connected with reduction of saving share in disposable income (Larionova et al., 2014).

The evolution of the consumption structure, which results from the sequence of life phases, requires chronological consideration of financial activities, in a manner concerning the accumulation of wealth. Competent in current times, the philosophy of individualism and consumerism promotes the attitude of living for the moment' and forces the attitudes of restraint and caution away from individual awareness on the social scale. Individual perceptions of one's income and material conditions are the basic factor shaping the conditions of saving and creating financial reserves (Roszkiewicz, 2014).

Less is known about consumer saving and well-being at the base of the pyramid, which includes over 3 billion people who live on less than US $\$ 2.50$ per day. Research evidence suggests that financial situation, and especially saving, is central to well-being in impoverished societies. In high-poverty societies, saving greatly improves well-being (Martin and Hill, 2015). Household improvements and aggregate self-perception of financial wellbeing, was obtained with access to quality savings accounts (Prina, 2015). Generous pension system, almost complete coverage of the public health- and long-term care insurance system in developed countries on the other side makes precautionary saving less necessary (Van Ooijen et al., 2015). The current rising levels of migration is a specific phenomenon, influencing the financial situation in the country of origin as well as the host countries through financial savings, migrants send back home (Ashraf et al., 2015). National household saving rate is negatively correlated with immigrants' saving rates, what may be driven by unaccounted remittances or changes in saving habits after immigration (Gatina, 2004). Consistent with theory and previous findings, households' saving ratios in Australia also tend to increase with income, but decrease with wealth and gearing. More at-risk households such as single-parent and migrant households tend to save more than other households, all else being equal (Finlay and Price, 2015).

Due to different history, the financial situation and household saving are unique among the Visegrad Four 
Countries (V4). Hanousek et al. (2007) in their analysis of financial sector of the V4 countries showed, that the households and non-financial companies are the largest creditors. In terms of debits, non-financial companies are the largest borrowers. They also found that the role of banks as mobilizers of savings from the non-financial sectors is substantial and that banking is not a declining industry in the V4 countries. Compared to a typical OECD country, Polish private and household saving rates are more affected by the process of financial deepening. They are also more sensitive to changes in government and corporate saving (Kolasa and Liberda, 2015). Roszkiewicz (2014) confirms the important role of subjective determinants of the accumulation of reserves, as well as the concept of the hierarchical model of financial actions contained in the theory of psychological economics is reflected in the actions of Polish households.

Household income, level of education, employment, ownership of long-term assets, and household size represent important factors that explain the amount of households' savings and their behaviour when choosing a portfolio of investments. Inflation increases the likelihood of investment into the capital market instruments (Temel Nalin, 2013; Šoltés and Gavurová, 2013; Filip, 2014; Michalski, 2008; Filla et al., 2015; Szabo et al., 2013; Glova, 2013; Bánociová and Pavliková, 2013; Tkáčová et al., 2015; Dráb et al. 2013; Jasinska-Biliczak, 2013).

The age composition of household members, and the related share of retired pensioners represents the change in the share of healthcare spending, which also reflects the level of social policies of individual states (Atella et al., 2015). Determining whether a particular household is saving enough for retirement, are complicated by substantial heterogeneity in household spending needs during retirement years. Longevity, health status, capital market returns, and whether family networks will prove a source of support or a drain, all vary significantly across households (Poterba, 2015).

Understanding of households' savings and investments is important for several reasons. At the national level, domestic investments are the main source of investment funding for both the government and the corporate sector. Rapid GDP growth leads to the growth of household incomes and higher rates of savings (Geetha and Vimala, 2014 Bod'a et al., 2014).

\section{Material and Methods}

The aim of the paper was to assess the development of household savings in the V4 countries based on the analysis of macroeconomic factors in 2005-2014. To assess the impact of those factors, it is necessary to know disposable income, household consumption, and consequently the amount of savings. The term households consisted of evaluation of domestic residents, sole traders, and non-profit institutions serving to households. Consequently, macroeconomic factors were set, including gross disposable income, gross domestic product, unemployment rate, and inflation rate, and then examined using multivariate regression analysis, where:

- response (dependent) variable represented:

- S: volume of gross savings (in the € millions)

- explanatory (independent) variables were:

- GDP: gross domestic production (in the € millions)

- UR: unemployment rate (in \%)

- IR: inflation rate (in \%)

- $\quad$ DI: gross disposable income (in the € millions)

We assumed that the change of variable $S$ can be explained by the changes of few other variables: GDP, UR, IR, and $\mathrm{DI}$, and that the relationship between the dependent variable and independent variables is linear. We wrote it as a single-equation econometric model:

$S=\beta_{0}+\beta_{1}{ }^{*} \mathrm{GDP}+\beta_{2}{ }^{*} U R+\beta_{3}{ }^{*} \mid R+\beta_{4}{ }^{*} D I+u_{t}$

where: $\beta 0, \beta 1, \ldots \beta 5$ are estimates of regression coefficients,

$\mathrm{u}_{\mathrm{t}}$ is a random component that includes unmeasurable random factors.

Model we have used, was considered ideal, when it does not contain heteroskedasticity, autocorrelation, multicolinearity, and if residues have a normal distribution. Eurostat (2015) and OECD (2015) data have been processed using R programming (R Core Team, 2012), and analysed to determine the influence of examined factors to the volume of households' investments. For all V4 countries: Czech Republic (CZ), Hungary (HU), Poland (PL) and Slovakia (SK), several models were used.

Investment creation was significantly affected by examined variables whose $p$-value was less than the predetermined value $a=0,05$. Appropriate choice of the model was suggested by the coefficient of determination, designating how many $\%$ of the variability in investment can be explained by the model. Model suitability could be confirmed also by the F-test of model's statistical significance. If the $p$-value was less than the predetermined value $(a=0,05)$, model was considered significant. In case the regression coefficients' estimates were unbiased, but the $p$ - 
values were incorrect, the wrong conclusion could be made because of the heteroskedasticity load (random parts had not constant variance). If the $p$-value of the Jarque-Bera test was higher than determined value $(a=0,05)$, it was considered as normal distribution of residuals. If the p-value was lower, the variable was eliminated from the model. Subsequently, the normality testing of residuals was carried out (Hušek, 1992).

Another test was used for detection of heteroskedasticity. If the p-value of Breusch-Pagan test was higher than $\alpha=0,05$; it was possible to confirm that the model is free of heteroskedasticity. Otherwise, the presence of heteroskedasticity was treated by elimination of the variable (Ochotinský et al., 2012). For identification of multicolinearity we focused to the VIF value (Variance Inflation Factors). If individual factors were lower than 5, or lower than 10 respectively, we could state that the model is not affected by multicolinearity. If the values were higher than 10 , the presence of multicolinearity was treated by removing the variable (Obtulovič, 2010).

The last test was used to detect the occurrence of autocorrelation. If the p-value of Breusch-Godfrey's test was higher than $\alpha=0,05$; we considered no autocorrelation was affecting the model. If the $p$-value was lower, presence of autocorrelation was treated by the Cochrane-Orcutt's method (Hušek, 1992). In case of all V4 countries, we have worked with several models. The model was considered ideal in case of no heteroskedasticity, autocorrelation, and multicolinearity, if residues had normal distribution; and if the variables were significantly affecting the model. Only the values of the resulting models are presented in the work.

\section{V4 Household Savings in 2005-2014}

Observation of development of saving is necessary to focus in particular to disposable income and consumption, as the gross disposable income is the own resource (fund) of consumption financing or the accumulation of savings.

Table 1: V4 households' gross disposable income in 2005-2014 (in € millions)

\begin{tabular}{cccccccc}
\hline SK & year change (\%) & CZ & year change (\%) & HU & year change (\%) & PL & year change (\%) \\
\hline 23.370 & - & 56.424 & - & 53.515 & - & 163.129 & - \\
26.277 & 12,44 & 63.494 & 12,53 & 52.973 & 2,78 & 178.688 & 9,54 \\
32.333 & 23,05 & 69.196 & 8,98 & 57.872 & 7,22 & 196.490 & 9,96 \\
38.310 & 18,49 & 82.329 & 18,98 & 59.878 & 3,47 & 229.520 & 16,81 \\
40.283 & 5,15 & 80.376 & $-2,37$ & 53.553 & $-10,56$ & 199.578 & $-13,05$ \\
41.954 & 4,15 & 84.309 & 4,89 & 55.476 & 3,59 & 226.264 & 13,37 \\
42.966 & 2,41 & 86.655 & 2,78 & 58.498 & 5,45 & 230.725 & 1,97 \\
43.702 & 1,71 & 85.886 & $-0,89$ & 57.170 & $-2,27$ & 244.357 & 5,91 \\
43.500 & $-0,46$ & 84.679 & $-1,41$ & 56.670 & $-0,87$ & 249.268 & 2,01 \\
45.684 & 5,02 & 88.785 & 4,85 & 58.760 & 3,69 & 252.390 & 1,25 \\
\hline
\end{tabular}

Source: own processing of Eurostat data (2015)

In all V4 countries until 2008 increase of disposable income was noticed, and in terms of pre-crisis development the Slovak Republic has achieved the greatest progress among the other V4 countries, when in the disposable income increase overtook the Hungary, Poland and Czech Republic (Table 1). Slovakia comparing to the neighbouring countries, managed to significantly improve its position in the generation of income. In 2008, it development of the global financial and economic crisis took place, due to which the value of disposable income in the Czech Republic decreased by 2,37\%, in Hungary by $10,56 \%$ and in Poland by $13,05 \%$ in 2009. Consumption growth this year was steeper than the increase in income. The influence of recession has decreased prices of many goods in all examined countries. Households took an advantageous offers of vendors, resulting in faster growth of consumption than income. Subsequently, since 2010, the values has increased gradually. The highest change in disposable income was recorded in the Slovak Republic in 2007, when the income was increased by $23,05 \%$.

The largest part of income comes from remuneration of employees. Regarding current expenditures, the growth was due to the growth of expenditure related to property income (interest paid on loans by households and other payments specified character) and current taxes on income and property. The lowest annual growth was recorded in other current expenditure transfers (payments for various types of non-life insurance, life and health insurance). After deduction of expenses from income households were left disposable income for other uses, which increased annually by $23,05 \%$. This income was used for final consumption (92,5\%) and the rest moved into the savings. 
Table 2: V4 household consumption in the period 2005-2014 (in € millions)

\begin{tabular}{|c|c|c|c|c|c|c|c|}
\hline SK & change of $\mathrm{C}(\%)$ & $C Z$ & Change of $\mathrm{C}(\%)$ & HU & change of $\mathrm{C}(\%)$ & PL & Change of $\mathrm{C}(\%)$ \\
\hline $21.907,7$ & - & $51.866,2$ & - & $47.716,8$ & - & $152.254,8$ & - \\
\hline $25.218,1$ & 15,11 & $57.547,5$ & 10,95 & $47.033,5$ & $-1,43$ & $166.935,0$ & 9,64 \\
\hline $30.706,3$ & 21,76 & $63.007,1$ & 9,49 & $53.313,9$ & 13,35 & $187.207,8$ & 12,14 \\
\hline $36.735,4$ & 19,63 & $75.644,6$ & 20,06 & $55.672,2$ & 4,42 & $222.054,9$ & 18,61 \\
\hline $37.929,9$ & 3,25 & $71.528,6$ & $-5,44$ & $48.420,6$ & $-13,03$ & $191.209,9$ & $-13,89$ \\
\hline $38.353,5$ & 1,12 & $75.935,1$ & 6,16 & $49.654,9$ & 2,55 & $217.895,5$ & 13,96 \\
\hline $39.582,9$ & 3,21 & $79.579,6$ & 4,80 & $51.159,6$ & 3,03 & $228.052,5$ & 4,66 \\
\hline $40.769,5$ & 3,00 & $78.351,1$ & $-1,54$ & $51.444,8$ & 0,56 & $234.031,8$ & 2,62 \\
\hline $40.994,5$ & 0,55 & $76.934,8$ & $-1,81$ & $51.384,2$ & $-0,12$ & $237.688,4$ & 1,56 \\
\hline $41.549,8$ & 1,35 & $79.450,0$ & 3,27 & $52.468,0$ & 2,11 & $239.760,0$ & 0,87 \\
\hline
\end{tabular}

Source: own processing according to Eurostat (2015)

In addition to the households' income the consumer spending are also important. Furthermore, the increased level of households' income allow them to spend more, thereby increasing their consumption. Income growth is accompanied by growth in consumption, with income growing faster than consumption, except for the crisis period (Table 2). The biggest change in consumption over the reporting period has seen the Slovak Republic, when, in 2007, household consumption increased by $21,76 \%$ compared to the previous year. Impact of the crisis has decreased the price of many goods and households used advantageous offers of the sellers, resulting in consumption grew faster than income.

In the Slovak Republic, the annual change in consumption of the population was positive each year. However, the annual change in consumption of the population in 2009 was negative in other V4 countries, which was caused by limiting of household consumption. Household consumption in examined countries was linked to the growth of wages, employment, as well as to the growth of gross mixed income (remunerations, gain of sole-traders). The population tried to adapt their consumption to the level of their income and save something at the same time.

As regards the structure of consumption expenditure, in all countries surveyed were most of the expenditures spent on housing, water, electricity, gas and fuel. The second largest item was expenditure on food and non-alcoholic beverages, and the smallest items were the expenditure on education, health, post and telecommunications, and clothing and footwear. As already mentioned, the main determinant of household final consumption growth is their disposable income. Income growth in individual countries was also reflected in the growth of consumption. Analysis carried out so far has showed that households respond to the income change flexibly and adapt the consumption expenditure, despite the fact that in 2009 recorded a steeper growth in consumption. A strong relationship between income and consumption, is presented by propensity to consume, which represents the share of consumption in income. Surveyed countries showed a high propensity to consume, still not reaching zero or negative saving (Figure 1). Household savings are substance of national saving of the economy and weakening of savings' creation could lead to distortions in the internal financial capacity of the economy.

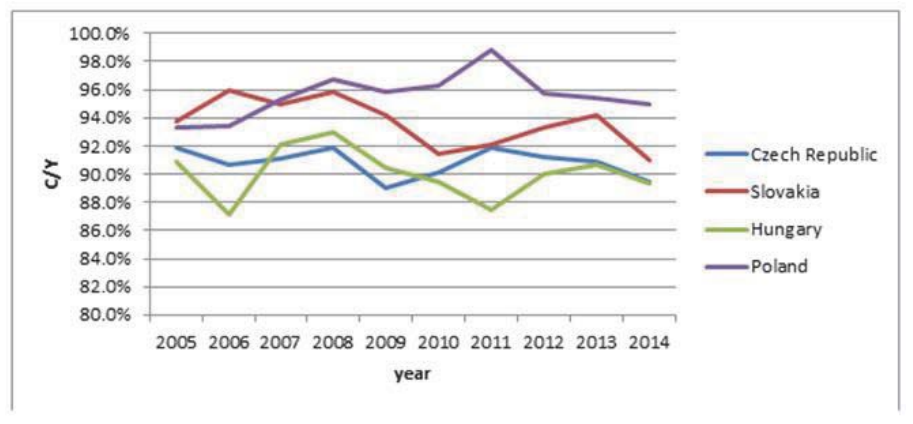

Figure 1: V4 households' propensity to consume in 2005-2014

Source: own processing according to Eurostat (2015) 
After mapping the recent development of disposable income and consumption we pass to the development of savings on, that is the amount of funds individual households in the surveyed countries were able to save. In the Table 3 development of savings was observed, assuming that if disposable income is growing, savings should grow as well, thereby increasing their share of the pension.

Table 3: V4 households' savings in 2005-2014 (in € millions)

\begin{tabular}{cccccccc}
\hline SK & change of S (\%) & CZ & change of S (\%) & HU & change of S (\%) & PL & change of S (\%) \\
\hline $1.869,0$ & - & $6.214,6$ & - & $4.798,2$ & - & $11.874,0$ & - \\
$1.659,1$ & $-11,23$ & $7.196,5$ & 15,80 & $6.939,5$ & 44,63 & $12.753,0$ & 7,40 \\
$2.952,7$ & 77,97 & $8.687,9$ & 20,72 & $4.558,1$ & $-34,32$ & $11.320,0$ & $-11,24$ \\
$3.641,2$ & 23,32 & $10.390,9$ & 19,60 & $4.205,8$ & $-7,73$ & $10.564,6$ & $-6,67$ \\
$2.366,5$ & $-35,01$ & $7.468,2$ & $-28,13$ & $5.132,4$ & 22,03 & $11.307,0$ & 7,03 \\
$2.760,9$ & 16,67 & $7.609,9$ & 1,90 & $5.821,1$ & 13,42 & $11.369,0$ & 0,55 \\
$3.221,1$ & 16,67 & $8.832,0$ & 16,06 & $7.338,4$ & 26,07 & $4.320,0$ & $-62,00$ \\
$2.988,8$ & $-7,21$ & $7.753,3$ & $-12,21$ & $5.725,2$ & $-21,98$ & $10.325,0$ & 139,00 \\
$3.133,9$ & 4,85 & $8.596,4$ & 10,87 & $5.285,8$ & $-7,67$ & $11.579,0$ & 12,15 \\
$4.687,7$ & 49,58 & $8.434,8$ & $-1,88$ & $6.292,0$ & 19,04 & $13.890,0$ & 19,96 \\
\hline
\end{tabular}

Source: own processing according to Eurostat (2015)

In the Czech Republic the growth in savings until 2008 was observed, which was replaced by the decline, and then since 2010 increase once again. In Hungary and Poland fluctuating development of savings was observed, i. e. rise followed by a fall. Similar to the development of disposable income, in the period of crisis occurs a significant drop in savings. In 2008 fell savings in Hungary and Poland by $7,73 \%$ and $6,67 \%$ respectively, in 2009 they fell in the Slovak Republic by 35,01\% and in the Czech Republic by $28,13 \%$. None of the reported countries showed negative savings. The highest savings change was observed in Poland in 2012, when the savings increased by $139 \%$ over the previous year. It is expected that in bad times, when households have lower pensions, they dip into savings or increase the loan.

Since 2010, the threat of lower incomes, or loss of employment respectively, has forced households to save more. Pécsyová et al. (2013) stated, that the Slovaks are saving considerably less than the EU average, and the reason for these differences is the wealth, income, the availability of credit, etc. Nevertheless, their indebtedness is still the lowest.

The highest popularity in the V4 countries among the possible forms of savings gained the building savings. The Slovak households have, moreover, quite a strong focus on cash, which is higher in comparison to the Czech Republic. This was also visible before the transition to Euro currency, when households in few months put into domestic banks about $€ 3,98$ billion (SKK 120 billion), while the greater part of which was returned in the form of new currency into the pockets of households even during 2009 (Rychtárik, 2012).

Figure 2 is mapping the inclination of households to savings' creation. During the surveyed period irregular development of this indicator was noted.

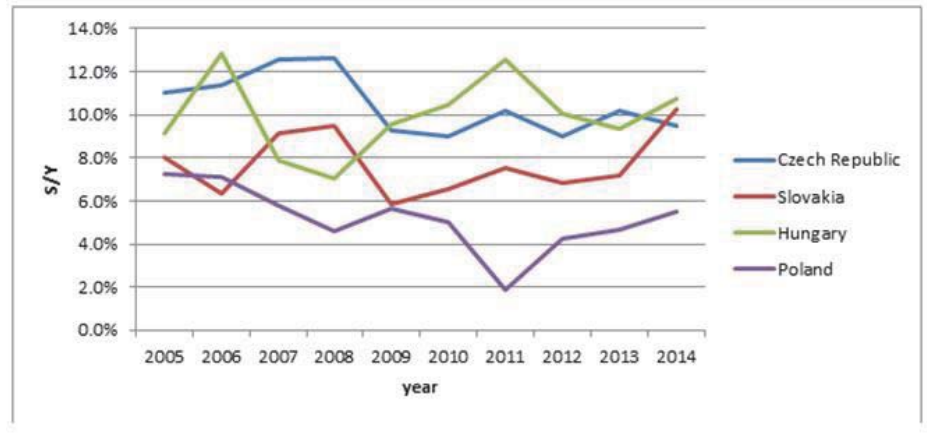

Figure 2: V4 households' propensity to save in 2005-2014

Source: own processing according to Eurostat (2015) 
Households didn't stop to save during the recession period. V4 countries were more careful and began to limit their consumption. The highest propensity to save was achieved in Hungary in 2006 (12,9\%). Countries with high savings rates (Hungary and the Czech Republic in our case), should not be that susceptible to the upcoming crisis. Propensity to save decreased in all V4 countries during 2008-2009, but a steep decrease occurred only in case of the Czech and Slovak Republic. Keynes emphasized already in 1936, that high savings could have a negative impact, reflected in the decline in consumption, thus a decrease in aggregate demand, production, output, employment resulting in decrease of incomes.

\section{Selected Macroeconomic Factors Affecting the Volume of Savings}

In this part we focused to the analysis of selected macroeconomic factors that affect the volume of savings. We chose the gross domestic product, unemployment rate, inflation rate and gross disposable income.

\subsection{Gross domestic product}

Figure 3 shows the development of GDP as an indicator of economic activity in the individual countries. This development represents a change in GDP comparing to the previous quarter for the period 2005-2014 (in \%). The pace of change in GDP was calculated as ( $\left.\mathrm{t}_{1}-\mathrm{t}_{0}\right) / \mathrm{t}_{0}$. In 2007 there was a slight increase in the Czech Republic and Poland compared to the previous year, which was influenced by consumption and investment mainly. Investment activity growth in all areas, and in terms of household consumption, consumption expenditure were affecting the growth in real household incomes, which grew faster than productivity. In Hungary and the Slovak Republic the pace of change in GDP has decreased, confirming the trend of economic slowdown from the previous year. Similar results were found by Raisová (2011).

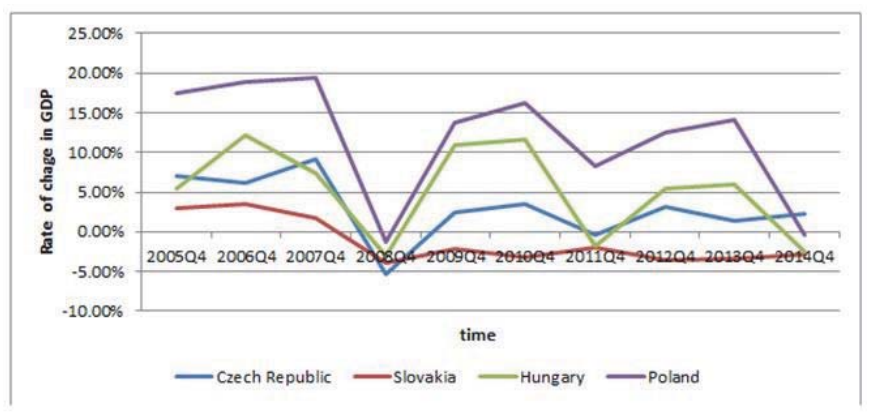

Figure 3: GDP development in V4 countries in 2005-2014, change from previous quarter (in \%)

Source: own processing according to Eurostat (2015)

In 2008, decline of the pace of change in GDP in all surveyed countries was observed, (the least fall was found in the Slovak Republic), resulting from the financial crisis. A year later there was a revival of the economy which affected the growth of gross disposable income. In 2011, a decline in pace of changes in GDP was recorded. Negative contribution to this decrease has the domestic demand, as investment and private consumption decreased. In late 2013, the rate of change in GDP remain almost unchanged; in Poland, Slovakia and Hungary a slight increase, while in the Czech Republic a slight decrease were noticed. In 2014, however, the Czech Republic recorded an increase in the rate of change in GDP, along with Slovak Republic, while in Poland and Hungary steep fall was reflected. Source of growth was household consumption and improvement in the labour market, the unemployment rate in Slovakia decreased by 1,7\% and in the Czech Republic by $1,2 \%$.

\subsection{Unemployment rate}

The second indicator is the unemployment rate (Figure 4), which had a fluctuating trend in the examined period. The best results were obtained by the Czech Republic, which in spite of the recession maintain single-digit unemployment rate. To the contrary, the worst results were observed in the Slovak Republic. The financial crisis impact has influenced also the 
labor market. Until 2008, the unemployment rate was decreasing in all V4 countries except Hungary, which recorded growth by the end of 2012. The unemployment rate has therefore deteriorated regardless of whether the financial crisis hit the country. However, till the end of 2012 it began to decline gradually, and in 2013 and 2014 it was the second lowest value of this indicator within the V4 countries (7,8\%). The Slovak Republic showed high levels of unemployment after 2008. The emergence of the crisis has negatively impacted this area, and within two years the indicator climbed up to $14,4 \%$. As part of the shock wave the collective redundancies of individuals occurred. The unemployment rate remain at this level till the end of 2013, when it began to decrease and got to the level of $12,6 \%$. Despite of this trend showed the Slovak Republic the worst results and remain the country with the highest unemployment rate within the V4 countries.

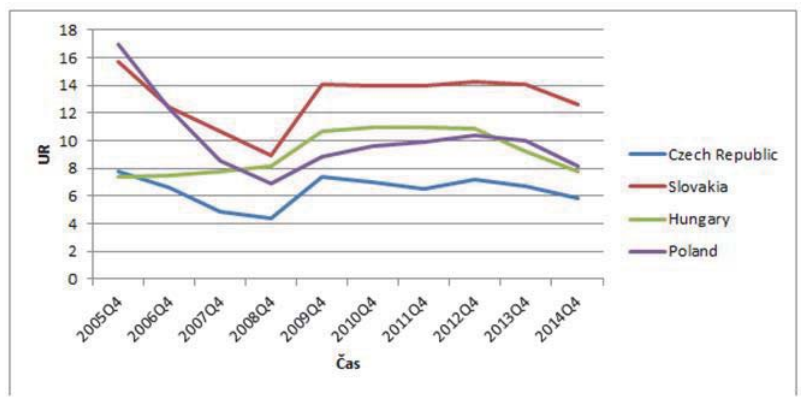

Figure 4: V4 unemployment rate in 2005-2014 (in \%)

Source: own processing according to Eurostat (2015)

The highest value over the past ten years was registered in Poland in 2005 (17,1\%). Since then, unemployment rate there was decreasing until 2008, when it reached the level of 6,9\%. The crisis has increased it again, but the increase was the second lowest among the V4 countries. The unemployment rate began to decline in late 2012, and reached 8,2\% in 2014. As regards the Czech Republic, the decline in the number of employed people showed an increase in the number of jobseekers and the unemployment rate by $3 \%$ in 2009. Over the last ten years all V4 countries managed to reduce the unemployment rate and this trend continues.

\subsection{Inflation rate}

The third examined variable was the inflation rate (Figure 5), which increased uncertainty about future incomes and thus increase the savings rate. This indicator is captured through the HICP (Harmonised Index of Consumer Prices). The inflation rate fluctuated in all V4 countries alternately and irregularly. Highest value was reached in Hungary in 2007 $(7,1 \%)$ where also the highest level of inflation rate among the V4 countries was recorded during the surveyed period. The acceleration of price level growth between 2006 and 2007 was caused mainly by services, food and adjustments in administered prices. After the onset of financial crisis, the value of inflation rate began to decrease from $7,1 \%$ to $4,2 \%$ at the end of 2008.

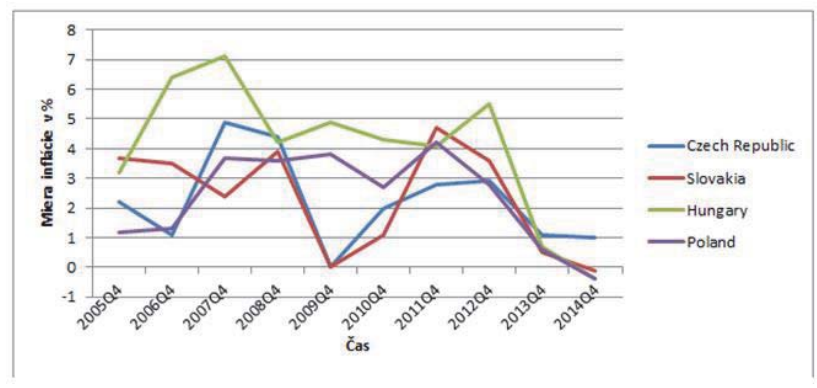

Figure 5: Development of inflation rate in V4 countries in 2005-2014 (\%)

Source: own processing according to OECD (2015) 
As in Hungary, also in other V4 countries, growth accelerated in the price level, most growth was registered in the prices of food and energies, influenced by global factors in 2007. In 2008, however, a decrease in inflation occurred, except the Slovak Republic, where the value of inflation rate increased by 1,5\%. The negative impact of the crisis began to show since 2008. High growth of indicator was in the Slovak Republic when the value climbed by 4,7\% till 2011, and in the Czech Republic by $2,8 \%$. While in 2009 , commodity prices have attenuated the price growth, increasing their prices, together with the gradual economic recovery in 2010 led to accelerated price growth. In 2010, the Slovak Republic was considered the country with the lowest inflation growth, but in next year belong among the countries with the fastest growing price level. Poland in the long term view has a positive assessment of the development, even with the variable character. Since the end of 2012, the inflation rate in all V4 countries gradually decreased, while in 2014 this parameter was at the level of decline $(-0.1 \%)$.

\subsection{Disposable income}

The last examined indicator, the disposable income, implies that richer households are saving more. A positive correlation between savings and disposable income was confirmed by the Friedman's theory, according to which the households begin to draw on their savings in case they consider the decline in their incomes is temporary. In case of permanent change in incomes they adjust the consumption.

Impact of selected macroeconomic factors on the amount of savings using regression analysis. In the following overview the results of comparison of saving models in individual V4 countries (Czech Republic: CZ, Hungary: HU, Poland: PL, Slovak Republic SK) have been processed.

Table 4: Values of the resulting models of investments in individual V4 countries

\begin{tabular}{lcccc}
\hline Country & CZ & HU & PL & SK \\
\hline Coeffic Coefficient of determination & 0,815 & 0,5045 & 0,804 & 0,833 \\
VIF-diff(GDP) & 3,955649 & 1,02364 & 1,96221 & 1,004988 \\
VIF-diff(DI) & 3,955649 & 1,02364 & 1,96221 & 1,004988 \\
p-value: & & & & \\
Diff (GDP) & $0,000142 * * *$ & $0,004913 * *$ & $0,0316^{*}$ & $0,001373 * *$ \\
Diff (DI) & $4,24 \mathrm{e}^{-11 * * *}$ & $1,36 \mathrm{e}^{-06} * * *$ & $1,24 \mathrm{e}^{-13} * * *$ & $<2 \mathrm{e}^{-16} * * *$ \\
-statistics & $6,562 \mathrm{e}^{-13}$ & $2,279 \mathrm{e}^{-06}$ & $<2,2 \mathrm{e}^{-16}$ & $<2,2 \mathrm{e}^{-16}$ \\
Jarque Bera Test & 0,7852 & 0,43 & 0,952 & 0,05681 \\
Breusch-Pagan test & 0,8111 & 0,2334 & 0,5841 & 0,08727 \\
Breusch-Godfrey test & 0,1116643 & 0,0616 & 0,417 & 0,6958359 \\
RESET test & 0,1068 & 0,1743 & 0,5833 & 0,3478 \\
\hline
\end{tabular}

Source: own processing

Table 5: Shape of the resulting models of investment in individual V4 countries

\begin{tabular}{lcccc}
\hline country & $\mathrm{CZ}$ & $\mathrm{HU}$ & $\mathrm{PL}$ & $\mathrm{SK}$ \\
\hline modified model & $\mathrm{S}=\beta 0+\beta 1^{*} \mathrm{GDP}+\beta 2^{*} \mathrm{DI}$ & $\mathrm{S}=\beta 0+\beta 1^{*} \mathrm{UR}+\beta 2^{*} \mathrm{DI}$ & $\mathrm{S}=\beta 0+\beta 1^{*} \mathrm{GDP}+\beta 2^{*} \mathrm{DI}$ & $\mathrm{S}=\beta 0+\beta 1^{*} \mathrm{UR}+\beta 2^{*} \mathrm{DI}$ \\
\hline estimates of & $\beta 0=-60,76162$ & $\beta 0=-13,5931$ & $\beta 0=-871,80973$ & $\beta 0=-67,83485$ \\
regression & $\beta 1=0,13799$ & $\beta 1=0,5438$ & $\beta 1=0,13323$ & $\beta 1=106,85133$ \\
coefficients & $\beta 2=0,64218$ & $\beta 2=2,0446$ & $\beta 2=1,30282$ & $\beta 2=0,75529$ \\
\hline resulting model & $\mathrm{S}=-60,76162+$ & $\mathrm{S}=-13,5931+$ & $\mathrm{S}=-871,80973+$ & $\mathrm{S}=-67,83485+$ \\
& $0,13799^{*} \mathrm{GDP}+0,64218^{*} \mathrm{DI}$ & $0,5438^{*} \mathrm{UR}+2,0446^{*} \mathrm{DI}$ & $0,13323^{*} \mathrm{GDP}+1,30282^{*} \mathrm{DI}$ & $106,85133^{*} \mathrm{UR}+0,75529^{*} \mathrm{DI}$ \\
\hline
\end{tabular}

Source: own processing

Based on results of regression model for the Czech Republic, it was found that a GDP and disposable income had the greatest impact on savings. From the basic model, which was significant only at 30,08\%; the UR variable was rejected because its $p$-value $(0,34730)>0,05$; followed by the IR variable, reaching the $p$-value $0,22015(>0,05)$. Two independent variables (GDP and $\mathrm{DI}$ ) remained in the model. If the disposable income has increased by a single unit with other variables unchanged, the savings would increase by 0,64218 units. By the given regression model we explained $81,5 \%$ of 
the variability in the volume of savings (Table 4). Residuals have a normal distribution, the model is absent of heteroskedasticity, autocorrelation, and multicolinearity as the p-values are higher than a 0,05.

In case of the Slovak Republic the greatest impact on savings had unemployment rate and disposable income. The IR variable, as it had a p-value of $0,7243(>0,05)$, and the GDP variable, which had a P-value of $0,0521(>0,05)$ were eliminated from the basic model with $70 \%$ significance. Two independent variables UR and D remained. In those it have been found, that if the disposable income will increase by a single unit, the savings will increase by 0,75529 units and, if the unemployment rate increased by single unit, savings will increase by 106,85133 units (Table 4). Model as a whole was statistically significant and explains $83 \%$ of variability in the volume of savings. Residuals have a normal distribution, model is heteroskedasticity, multicolinearity, and autocorrelation free, as the $p$-values are higher than 0,05 .

In Poland, as well as in the Czech Republic the biggest impact had GDP and disposable income. The model had $90 \%$ significance, the IR variable with a p-value of $0,7581(>0,05)$ and the UR variable, with a p-value of $0,5398(>0,05)$ were excluded. Two independent variables GDP and DI remained. In those it was found that when disposable income increases by single unit, savings will increase by 1,30282 units, and if the GDP increases by a single unit, savings will increase by 0,13323 units. Just in the contrary, in the Czech Republic the growth of this variable caused decline in savings (Table 4). Residuals had a normal distribution, model was free of heteroskedasticity, multicolinearity, and autocorrelation, as the $p$-values were higher than 0,05 .

In Hungary and Slovakia the greatest impact had unemployment rate and disposable income. The basic model of Hungary was the only one in which all the variables were statistically significant. Since it was necessary to logarithm the model, IR and GDP variables have been excluded, thus we got a new model, consisting of logarithmized UR and DI. If the disposable income will be increased by a single unit, savings will increase by 2,0446 units. If the unemployment rate will be increased by a single unit, savings will increase by 0,5438 units. Residuals had a normal distribution, model was absent of heteroskedasticity, multicolinearity, and autocorrelation, as the $p$-values were higher than 0,05 .

\section{Conclusion}

The subject of an increasing interest of households is focused to the decisions about how much of their disposable income will be used for their current or future consumption. Our multidimensional regression analysis confirmed the fact that disposable income is the most important determinant of consumption and savings. In all V4 countries a strong positive impact of household disposable income to the volume of savings was confirmed, i.e. growth in disposable income caused the growth of savings. In the Slovak Republic annual increase of the disposable income within the period 20052014 vary from $-0,46 \%$ to $23,05 \%$; $92,5 \%$ were used for the final consumption and the rest $(7,5 \%)$ was transferred to the savings. In general, wealthier households are saving more. Another important determinant is the GDP, which impact to the amount of savings was significant in the Czech Republic (17,53\%) and Poland (16,20\%). The growth of the Czech and Polish economy was influenced mainly by foreign demand; domestic demand declined due to lower household consumption, thus the savings has increased. On the other hand, in the Slovak Republic and Hungary it was the unemployment rate, which significantly affected the volume of the savings (Slovak Republic: 8,9-14,3\%, Hungary: 6,7$11,2 \%)$. Based on our results we can state that the inflation rate did not belong to an important determinants in any of V4 countries. In all analyzed countries inflation has moved alternately and irregularly. Since 2012, there has been a gradual decrease, and currently it ranges from -0,1\% (Slovak Republic) to 1\% (Czech Republic).

\section{References}

Ashraf, N., Aycinena, D., Martinez A. C., \& Yang, D. (2015). Savings in transnational households: A field experiment among migrants from El Salvador. Review of Economics and Statistics, 97, 2, 332-351.

Atella, V., Brugiavini, A., \& Pace, N. (2015). The health care system reform in China: Effects on out-of-pocket expenses and saving. China Economic Review, 34, 182-195.

Bánociová, A. \& Pavliková, L'. (2013). Application of econometric model in the studies of factors affecting the income tax of legal entity in the Slovak Republic. Journal of Applied Economic Sciences, 8, 2, 141-153.

Bod'a, M., Pinter, L., \& Zimková, E. (2014). Nominal exchange rate and sovereign credit default swaps: Cointegration and granger causality. Ekonomický časopis, 62, 1, 46-70.

Dráb, R. \& Mihóková, L. (2013). Determinants of fiscal consolidation success in V4 countries. Financial Aspects of Recent Trends in the Global Economy. (Vol. 2), 220-243.

Eurostat (2015). GDP and main components (output, expenditure and income) 2005Q1-2014Q4. [Online] Available:

http://appsso.eurostat.ec.europa.eu/show.do?dataset=namq10gdp\&lang=en (February 28, 2015)

Fila, K., Schwarczová, L., \& Mura, L. (2015). Citizen satisfaction survey as a tool of citizen relationship management of local government 
in Slovakia. Serbian Journal of Management, 10, 1, 117-129.

Filip, P. (2014). Strategies of financing and capital allocation at Polish enterprises under crisis conditions. Actual Problems of Economics, $161,11,179-185$.

Finlay, R., \& Price, F. (2015). Household saving in Australia. BE Journal of Macroeconomics, 15, 2, 677-704.

Gatina, L. (2014). The saving behaviour of immigrants and home-country characteristics. Evidence from Australia, Australian Economic Review, 47, 2, 157-172.

Geetha, S. N., \& Vimala, K. (2014). Perception of household individual investors towards selected financial investment avenues (with reference to investors in Chennai city). Procedia Economics and Finance, 11, 360-374.

Glova, J. (2013). Exponential smoothing technique in correlation structure forecasting of Visegrad country. Journal of Applied Economic Sciences. 8, 2, 184-190.

Hanousek, J., Kocenda, E., \& Ondko, P. (2007). The banking sector in new EU member countries: A sectoral financial flows analysis, Finance a Uver-Czech. Journal of Economics and Finance, 57, 5-6, 200-224.

Hušek, R. (1992). Základy ekonometrie. (1 st ed.). Praha: Vysoká škola ekonomická v Praze.

Jasińska-Biliczak, A. (2013). The Role of Concept papers of the region in the process of supporting the small and medium entrepreneurship. Acta Oeconomica Universitatis Selye, 2, 1, 9-16.

Kolasa, A., \& Liberda, B. (2015). Determinants of saving in Poland: Are they different from those in other OECD countries? Eastern European Economics, 53, 2, 124-148.

Larionova, N., Varlamova, J., \& Singatullina, G. (2014). The trends on household economic behavior in emerging countries of Europe. Procedia Economics and Finance, 15, 421-429.

Michalski, G., (2008). Operational risk in current assets investment decisions: Portfolio management approach in accounts receivable. Agricultural Economics, 54, 1, 12-19.

OECD (2015). HICP 2005Q1-2014Q4. [Online] Available: http://stats.oecd.org/index.aspx?queryid=24893\# (July 7, 2015)

OECD (2015). Monetary and Financial statistics: Long-term interest rates 2005Q1-2014Q4. [Online] Available: http://stats.oecd.org/ viewhtml.aspx?datasetcode=MEI_FIN\&lang=en (July 24, 2015)

OECD (2015). Gross disposable income of households, 2005Q1-2014Q4. [Online] Available: http://stats.oecd.org/index.aspx?queryid= $350 \#$ (May 10, 2015)

OECD (2015). Gross saving of households, 2005Q1-2014Q4. [Online] Available: http://stats.oecd.org/index.aspx?queryid=350\# (May 2, 2015)

Obtulovič, P. (2010). Ekonometria. (1st ed.). Nitra: SPU.

Ochotinský, P. (ed.) (2012). Úvod do ekonometrie pre financie. (1 st ed.). Bratislava: Vydavatel'stvo Ekonóm.

Pécsyová, M., Vaňko, M., \& Machlica, G. (2013). Determinanty miery úspor na Slovensku. [Online] Available: http://www.nbs.sk/_img/ Documents/_PUBLIK_NBS_FSR/Biatec/Rok2013/10-2013/03_biatec13-10_pecsyova2.pdf (July 15, 2015)

Poterba, J. M. (2015). Saver heterogeneity and the challenge of assessing retirement saving adequacy. National Tax Journal, 68, 2, $377-388$.

Prina, S. (2015). Banking the poor via savings accounts: Evidence from a field experiment. Journal of Development Economics, 115, 1631.

R Core Team R (2012). A language and environment for statistical computing. R Foundation for Statistical Computing, Vienna, Austria, [Online] Available: http://www.R-project.org/ (July 20, 2015)

Raisová, M. (2011). Analysis of the mutual relation between investments and GDP - Granger causality test. Transactions of the Universities of Kosice. 3, 78-83.

Roszkiewicz, M. (2014). Objective and subjective factors shaping saving behaviours - the case of Polish households. International Journal of Consumer Studies, 38, 6, 602-611.

Rychtárik, Š. (2012). Finančné aktíva a pasíva slovenských domácností. [Online] Available: http://www.nbs.sk/_img/Documents/_ PUBLIK_NBS_FSR/Biatec/Rok2012/2-2012/01_biatec12-2_rychtarik.pdf (May 8, 2015)

Szabo, Z., Šoltés, M., \& Herman, E. (2013). Innovative capacity and performance of transition economies: Comparative study at the level of enterprises. E+M Ekonomie a Management,16, 1, 52-68.

Šoltés, V., \& Gavurová, B. (2013). Application of the cross impact matrix method in problematic phases of the balanced scorecard system in private and public sector. Journal of Applied Economic Sciences, 8, 1, 99-119.

Temel Nalin, H. (2013). Determinants of household saving and portfolio choice behaviour in Turkey. Acta Oeconomica, 63, 3, 309-331.

Tkáčová, A., Siničáková, M., \& Králik, A. (2015). Industrial indicators and their influence on the V4 countries business cycles. Actual Problems of Economics, 164, 2, 169-178.

Van Ooijen, R., Alessie, R., \& Kalwij, A. (2015). Saving behaviour and portfolio choice after retirement. Economist-Netherlands, 163, 3 , 353-404. 